\section{Activities of the European International Division of the Royal College of Psychiatrists}

For contributions

to the News,

Notes, Events

column, please

contact Brian

Martindale, South

of Tyne Early

Intervention in

Psychosis Service,

Northumberland

Tyne and Wear

NHS Trust,

Monkwearmouth

Hospital,

Newcastle Road,

Sunderland SR5

1NB, UK, email

Brian.Martindale@ stw.nhs.uk ised a number of symposia: Athens (March 2005) (September 2005) (May 2006) 2006)
The Division has been in correspondence with its members asking for collaboration. It has also organ-

O 'Royal College of Psychiatrists Travels Overseas', at the WPA Regional and Intersectional Congress in

o 'European Division: Launching and Perspectives', during the 13th World Congress of Psychiatry

O 'European Division of the Royal College of Psychiatrists: Activities and Perspectives', during the 19th Panhellenic Congress of Psychiatry in Athens

O participation in a symposium organised by the Pan-American Division of the College in Toronto, Canada, on Migration and Mental Health (May

o 'Psychiatric Education in Europe' at the College annual meeting in Glasgow and participation by the Division chair at the College's World Psychiatric Association Liaison Meeting (July 2006).

A major aim of the Division will be the provision of educational opportunities and expertise on the organisation of mental health services for psychiatric associations and individual colleagues in Eastern Europe. Joint activities with the Psychiatric Association for Eastern Europe and the Balkans (affiliated with the World Psychiatric Association) will be scheduled and experts from Western Europe will provide teaching and direct courses in Eastern Europe.

George Christodoulou

Chair, European International Division

\section{The International Divisions at the College annual general meeting}

All six International Divisions contributed well received symposia to the Glasgow meeting in July:

o The European Division took part in the trainees' day and the speakers (Christodoulou, Lindhardt and Bomba) covered themes ranging from the values of psychiatry from antiquity, to the European-wide training recommendations for psychiatry from the European Union of Medical Specialists (UEMS) and the specific developments in Poland integrating historical and European trends.

- The African Division speakers (Zabow, Ndetei and Olugbile) gave insightful and informative papers on areas of conflict and complementarities between African traditional healers and psychiatry.

o The theme of alternative and complementary medicine in relation to psychiatry was continued by the Pan-American Division (Kisely, Meehan) and then the potential role of anti-oxidants in schizophrenia was outlined by Fernandez.

O The Western Pacific and South Asia Divisions joined to focus on the need to develop effective training and interventions in primary and community care, including inter-regional cooperation (Deva, Rajkumar, Javed, Mufti, Mendis and Chaudhry).

O The Middle East Division (Kamel, Taha and ElGaddal) focused on several aspects of the family in working with drug misuse, schizophrenia and attempted suicide as well as post-traumatic stress disorder.

The organisation of the symposia this year allowed for greater dialogue with those attending.

\section{Association of European Psychiatrists conference, 2007}

It is our pleasure to invite you to attend the 15th European Congress of Psychiatry on European Psychiatry, Science and Art, in Madrid, Spain, 17-21 March 2007, organised by the Association of European Psychiatrists. The high-quality scientific programme will open new perspectives on the science and art of psychiatry and on issues related to treatment and patient care through state-of-the-art lectures, plenary lectures and core symposia. The Congress will also serve the educational mission of the Association through a variety of courses (continuing medical education with accreditation from the European Union of Medical Specialists), workshops, lectures and symposia. Information, proposals and registrations are available at http://www.kenes.com/aep2007.

Henning Sass AEP President Juan J. Lopez-Ibor Local Organising Committee Chairman

\section{WPA Permanent Secretariat}

The World Psychiatric Association (WPA) now has a Permanent Secretariat with its headquarters based in Geneva. The contact details are: World Psychiatric Association Secretariat, Psychiatric Hospital, Pavillon Les Voirons, 2, Chemin du Petit Bel-Air, 1225 ChêneBourg, Geneva, Switzerland, tel. +4I 223055737 , fax+4I 22305 5735, email wpasecretariat@wpanet. org. Members of the College are very welcome to visit the offices in Geneva. Anna Engstrom is the Administrator and Pamela Atiase the Deputy Administrator. The WPA website is http://www.wpanet.org, where contact details can be found for the extensive range of scientific sections of the WPA, all of which would welcome personal communications and contact from individual College members. 